\title{
Achievements in Genetic Engineering of Amaranthus L. Representatives
}

\author{
Olha Yaroshko (iD) 1 *
}

${ }^{1}$ Institute of cell biology and genetic engineering NAS of Ukraine, Department of genetic engineering, Kyiv, Ukraine

\begin{abstract}
Despite the fact that in the modern world more than a thousand edible plants are used for food, only 3 staple cereal crops are grown worldwide: wheat, rice, and maize. Growing a limited number of crops often causes many problems: ranging from the loss of biodiversity, due to the constant cultivation of the same monocultures in the same areas, to the deterioration of soil quality. A way out of this situation is the selection of new untraditional and neglected plants that could grow in a wide range of temperatures, produce high yields and at the same time have a balanced amino acid composition. Pseudocereals of the genus Amaranthus L. meet these criteria. Amaranth grain and plant raw materials are used in many industries: food, medicine, cosmetics.

Modern technologies do not stand still. Along with traditional methods of plant breeding, the rapid pace of development involves genetic engineering of plants, which allows the process of creating improved plants to be speeded up several times.

The purpose of this study is to analyze and systematize the achievements in the field of regeneration and genetic transformation of representatives of the Amaranthus genus. The results can be used for a practical application: the genetic transformation of species of the genus Amaranthus and other close genera of plants.
\end{abstract}

\section{ARTICLE HISTORY}

Received: Apr. 12, 2021

Revised: June, 072021

Accepted: June 10, 2021

\section{KEYWORDS}

Amaranthus,

Regeneration, Transformation

\section{INTRODUCTION}

Amaranth is a high-yielding plant. From 1 plant it is possible to obtain more than 5,000 seeds. Moreover, amaranth has a uniquely balanced amino acid composition that ensures easy digestion. Amaranth is a rich source of protein and essential amino acids, deficits of which cannot be compensated by traditional agricultural crops.

Furthermore, amaranths are used in medicine. Amarantin substance $\left(\mathrm{C}_{29} \mathrm{H}_{31} \mathrm{~N}_{2} \mathrm{O}_{19}\right)$ was derived from some species of amaranth (A. caudatus L., A. tricolor L., A. cruenthus L.) (Yaacob et al., 2012). Amarantin relates to alkaloids-betalains. It has useful antioxidant properties in the human organism (Burd, 2006).

Due to the fact that amaranths are indifferent to the type of soil and are drought-resistant, they are grown as a grain crop in countries with a temperate climate (Western Europe), as well

\footnotetext{
*CONTACT: Olha YAROSHKO $\bigotimes$ 90tigeryaroshko90@gmail.com Institute of Cell Biology and Genetic Engineering NAS of Ukraine, Department of Genetic Engineering, Kyiv, Ukraine
} 
as in hot-climate countries, where many traditional crops grow poorly: Mexico, the USA, African countries, India.

Given that amaranth is one of the main food crops in India and Africa, has a unique rich amino acid composition with a high nutritional value, and can serve as a source of biologically active substances for further use in medicine, amaranth plants have undergone improvements for many decades using hybridization, selection and mutagenesis methods.

In recent years, the chemical composition of plants and some agronomic properties have begun to improve using biotechnological methods, namely genetic engineering. Genetic engineering methods make it possible to improve not only the useful properties of a plant, but also to provide additional useful characteristics during plant transformation.

Since it is known that the percentage of Agrobacterium - mediated transformation of plants is often low, usually even before this transformation possible ways of obtaining a large number of transformed plants from a single parent plant are consequently worked out. One of the optimal methods of rapidly increasing the number of plants is considered to be direct regeneration of plants in vitro conditions.

Therefore, we first consider the main achievements related to obtaining regenerants of amaranths in vitro.

\section{ACHIEVEMENTS IN REGENERATION OF AMARANTHUS L. SPECIES}

To date, there have been many studies on the regeneration and callus formation of amaranth. Basically, the researchers who obtained calluses, had as primary objective their use as a source of secondary metabolites and other valuable substances. In this connection, the largest number of studies devoted to amaranths have had a biochemical orientation.

Amin and colleagues verified the possibility of obtaining the Amaranthus gangeticus L. callus. The leaves, stems and roots were used as initial explants. The scientists observed the formation of calluses in $99.7 \% \pm 0.2 \%$ of explants which were derived from stem calluses on MS medium supplemented with $2.0 \mathrm{mg} / 1 \mathrm{NAA}(\alpha-\mathrm{Naphthalene}$ acetic acid $)+1.0 \mathrm{mg} / \mathrm{l} \mathrm{BA}(6-$ benzylaminopurine) (Amin et al., 2015).

The group headed by Bennici studied the morphogenesis and growth of calluses. As an object of investigation, they chose lines of several species: A. caudatus L., (PI490458, AMES15114, AMES5461), A. cruentus L. (434, 622, AMES2248, AMES2247, PI511731, PI777913), A. hybridus L. (1047), A. hypochondriacus L. (1221, 718, 674, 722, 412, PI540446). The stem segments derived from 15-day sprouts were used for explants (Bennici et al., 1997).

Callus tissue was obtained from the explants of the lines A. caudatus L. (Bennici et al., 1997), A. cruentus L. (Bennici et al., 1997) and A. hypochondriacus L. (Bennici et al., 1997) on MS medium with the addition of $2.3 \mu \mathrm{M} 2.4-\mathrm{D}$ (2,4-dichlorophenoxyacetic acid) $+2.3 \mu \mathrm{M}$ KIN (kinetin); NAA from $0.5 \mu \mathrm{M}$ to $5.4 \mu \mathrm{M}+\mathrm{BA}$ from $0.4 \mu \mathrm{M}$ to $13.3 \mu \mathrm{M}$.

The callus formation was observed in $100 \%$ of explants, with the exception of two lines of A. caudatus L. and three lines of A. cruentus L. and A. hypochondriacus L.. Different concentrations of NAA + BA did not induce callus formation on the A. caudatus explants line AMES5461, while $5.4 \mu \mathrm{M}$ NAA $+13.3 \mu \mathrm{M}$ BA caused callus formation only in $43 \%$ of PI490458 A. caudatus L. explants. A. cruentus L. lines formed calluses in percentage ratios of less than 100\%: AMES2247, 71\% on MS medium, with addition of $5.4 \mu \mathrm{M}$ NAA $+4.4 \mu \mathrm{M}$ BA; PI511731, 60\% on MS medium with addition of 2,4-D + KIN and $67 \%$ on MS medium with addition of $5.4 \mu \mathrm{M}$ NAA $+13.3 \mu \mathrm{M}$ BA; PI477913 $-75 \%$ on $2,4-\mathrm{D}+\mathrm{KIN}$ and $79 \%$ on MS medium with addition of $5.4 \mu \mathrm{M}$ NAA $+4.4 \mu \mathrm{M}$ BA. 
Plant regenerants were obtained for A. hybridus L. (line 1047) and for A. hypochondriacus L. (line 674). The rate of regeneration was low - 8.5\% (A. hybridus L.) and 14.3\% (A. hypochondriacus L.). Regenerants were also obtained for A. hybridus L., $A$. hypochondriacus L., A. cruentus L. on MS medium with addition of $2.7 \mu \mathrm{M}$ NAA $+2.5 \mu \mathrm{M}$ $2 \mathrm{iP}\left(\mathrm{N}^{6}-(2\right.$-isopentenyl)adenine), $2.7 \mu \mathrm{M}$ NAA $+2.3 \mu \mathrm{M}$ KIN. The regenerants of $A$. cruentus L. line 434 and 1034 were obtained on MS medium with addition of $2.7 \mu \mathrm{M} \mathrm{NAA}+4.4 \mu \mathrm{M}$ BA. The general conclusion of the authors was as follows: the absolute majority of species and lines of amaranths are able to form calluses on most media tested by the authors (almost 100\% of callus formation). There was no clear connection between regeneration of shoots and the use of growth regulators. This is due to the strong influence of the genotype of plants on organogenesis. Amaranths have high levels of cytokinins (auxins), which inhibit regeneration processes. The authors believe that the best stimulator of amaranth regeneration was BA.

Mousumi Biswas and colleagues conducted experiments aimed at obtaining calluses for further isolation of betacianins from them (Biswas et al., 2013). The biggest volumes of callus synthesizing betacianins were obtained from explants of stem origin on MS medium supplemented by NAA $(0.25 \mathrm{mg} / \mathrm{l})+\mathrm{BA}(2 \mathrm{mg} / \mathrm{l})$. In addition, researchers found red-purple amaranthine pigment in the callus lines, 2 new yellow pigments and 18 other biologically active phenylpropanoids. A new betaxanthin has been identified and a methyl derivative of arginine betaxanthin was also identified. Pigments were purified by size exclusion chromatography (Biswas et al., 2013).

Flores and colleagues studied the formation of callus and regeneration for the A. hypochondriacus L., A. cruentus L. and A. tricholor L. species. They observed a rapid growth of calluses and abnormal roots on A. hypochondriacus L. and A. cruentus L. leaf disks on MS medium in the presence of $0.1-1.0 \mathrm{mg} / 1$ of $2.4-\mathrm{D}$. At higher levels $(1.0-10.0 \mathrm{mg} / \mathrm{l})$ of 2,4-D, embryo-like structures formed from the surfaces and veins of the leaf discs. Shoots were formed from hypocotyl derivative callus on the medium B5 $+0.1 \mathrm{mg} / 1 \mathrm{NAA}$ and $0.1-1.0 \mathrm{mg} / \mathrm{l}$ ZEA (zeatin). Lower ratios of ZEA/NAA stimulated the formation of roots from hypocotyl segments (Flores et al., 1982).

Gajdošová, with a team of researchers, selected the ideal conditions for the regeneration and cultivation of Amaranthus cruentus L. 'Ficha' and Amaranthus hybridus (Gajdosova et al., 2007; Gajdosova et al., 2013) 'K-433'. As explants, they used epicotyls with the first pair of leaves, hypocotyls, roots and segments of the leaves of 10-day seedlings. For both species studied, the most effective media for direct regeneration from epicotyls were $\mathrm{MS}_{30}$, supplemented with $5 \mathrm{mg} / 1 \mathrm{BA}+0.01 \mathrm{mg} / 1 \mathrm{NAA}, \mathrm{MS}_{30}$ supplemented with $1 \mathrm{mg} / 1 \mathrm{TDZ}$ (thidiazuron), $\mathrm{MS}_{30}$ supplemented with $3 \mathrm{mg} / 1 \mathrm{TDZ}+0.01 \mathrm{mg} / 1 \mathrm{NAA}$. The most effective medium for induction of callus was $\mathrm{MS}_{30}$ with $6 \mathrm{mg} / \mathrm{l} \mathrm{NAA}+0.1 \mathrm{mg} / \mathrm{l} \mathrm{BA}$ (for Amaranthus cruentus L. 'Ficha') and $\mathrm{MS}_{30}+2 \mathrm{mg} / 12.4 \mathrm{D}+0.5 \mathrm{mg} / \mathrm{l} \mathrm{BAP}$ (for Amaranthus hybridus L. "K433"). The authors made the following conclusions: in order to obtain regenerants, it is necessary to use mediums with a high cytokinin content: auxins; amaranths are characterized by a high callus forming ability, almost $100 \%$ on all tested mediums; regenerants were obtained only from epicotyl segments; the ability to regenerate strongly depends on the genotype, age of plants and used types of explants; the overall regeneration frequency was low (Gajdosova et al., 2007; Gajdosova et al., 2013).

Flores and colleagues investigated the regeneration ability and the callus formation of the following species: A. hypohondriacus L., A. cruentus L., A. tricolor L.. Parts of the hypocotyls were used as explants. The regeneration was indirect (first, callus tissue was obtained). The scientists concluded that the optimal medium for regeneration is B5 supplemented with $0.1 \mathrm{mg} / 1$ $\mathrm{NAA}+0.1-1.0 \mathrm{mg} / 1 \mathrm{ZEA}$. The callus tissue was obtained from leaf discs of $A$. hypohondriacus L. and $A$. cruentus L. Intensive growth of the callus was observed on $\mathrm{MS}_{30}$ medium with 0.1-1 
$\mathrm{mg} / 1$ 2,4-D. However, after addition to the $\mathrm{MS}_{30}$ medium of $0.2 \mathrm{mg} / \mathrm{l} \mathrm{BA}+2 \mathrm{mg} / \mathrm{l} \mathrm{NAA}$ and $10 \%$ coconut water, they observed shoot induction from callus tissue (Flores \& Teutonico, 1986).

The team of researchers headed by Bennici intended to obtain regenerants for the following species: A. hypohondriacus L., A. cruentus L., A. hybridus L., A. caudatus L. As explants, hypocotyls were used. Regeneration was obtained for 2 species as a result: $A$. hypochondriacus L. $\left(\mathrm{MS}_{30}+3 \mathrm{mg} / 1 \mathrm{BA}+1 \mathrm{mg} / 1 \mathrm{NAA}\right)$, A. caudatus L. $\left(\mathrm{MS}_{30}+3 \mathrm{mg} / 1 \mathrm{KIN}+0.3 \mathrm{mg} / \mathrm{lAA}\right.$ (indole-3-acetic acid). The percentage of regeneration was low (26\%). At the same time as the main objective of obtaining regenerants, researchers obtained a callus tisssue. Rapid and intensive callus formation from hypocotyl explants was observed for A. cruentus $\mathrm{L}$. (6 mg/l $\mathrm{NAA}+0.1 \mathrm{mg} / \mathrm{l} \mathrm{BA}$ ) and . hybridus L. (6 mg/1 2.4-D + $0.1 \mathrm{mg} / 1 \mathrm{KIN}$ (Bennici et al., 1992). Arya and colleagues chose $A$. paniculatus L. as an object of research. Parts of the inflorescence were used as explants. When transferring the explants on the $\mathrm{MS}_{30}$ medium with 8-15 mg/l $\mathrm{KIN}$ or $\mathrm{MS}_{30}+5-10 \mathrm{mg} / \mathrm{l} \mathrm{BA}$, secondary inflorescences were formed from stems and leaves of the primary inflorescence buds (Arya et al., 1993). Bui van Le and colleagues received regenerants of A. edulis L. from thin cell layers. For experiments, they used thin slices $(0.2-0.4$ $\mathrm{mm}$ ) of cotyledons, hypocotyls, roots, tissues from the apical and sub-apical areas. Explants were obtained from 7-day seedlings (Bui van Le et al., 1998). Regenerants were obtained solely from tissues taken from the apical and sub-apical zone. Only callus tissue was obtained from all other types of explants.

Initially, embryonic buds were formed from the tissues of the apical and sub-apical zone on a medium of $\mathrm{MS}_{5}+2 \mu \mathrm{M} \mathrm{TDZ}+10 \mu \mathrm{M}$ of CPPU (forchlorfenuron). These embryonic buds were then transferred on $\mathrm{MS}_{5}+10 \mu \mathrm{M}$ BAP for elongation of stems (Bui van Le et al., 1998). Tisserat and Galletta obtained only callus tissue for A. gangenticus, A. hypochondriacus, A. caudatus L., A. viridis L., A. retroflexus L. (Tisserat \& Galletta, 1988). Callus tissue was obtained by Yaacob and colleagues. Callus was obtained for further extraction of biologically active substances using leaves, stems, roots on $\mathrm{MS}_{30}+1.5 \mathrm{mg} / 1 \mathrm{IAA}+0.5 \mathrm{mg} / 1$ of ZEA or $\mathrm{MS}_{30}$ + $1 \mathrm{mg} / \mathrm{l}$ IAA medium (Yaacob et al., 2012).

A team of researchers headed by Bagga, studied the regeneration ability and callus formation of $A$. paniculatus L. The hypocotyls were used as the explants. Regeneration of 1-2 shoots from one end of the hypocotyls explants was obtained on medium $\mathrm{B}_{5}+1 \mathrm{ppm} \mathrm{KIN}+1$ ppm NAA; on medium $\mathrm{B}_{5}+0.5 \mathrm{mg} / 1 \mathrm{KIN}+0.1 \mathrm{mg} / 1 \mathrm{NAA}$ numerous buds formed (10-14 pieces), from which stems developed later. Intensive callus growth was observed on medium $\mathrm{B}_{5}+1 \mathrm{mg} / \mathrm{l}$ $\mathrm{GA}_{3}$ (gibberellic acid) + $1 \mathrm{mg} / 1 \mathrm{KIN}+1 \mathrm{mg} / 1$ 2,4-D (Bagga et al., 1987).

Jofre-Garfias and co-authors obtained embryos from the cotyledons of A. hypochondriacus L. cv. Azteca on medium $\mathrm{MS}_{3}+10 \%$ coconut milk and $\mathrm{MS}_{3}+10 \mu \mathrm{M}$ 2.4-D (Jofre-Garfias et al., 1997). Pal and colleagues obtained A tricolor regenerants from hypocotyls and epicotyls of 7-day seedlings on $\mathrm{MS}_{30}+13.2 \mu \mathrm{M} \mathrm{BA}+1.8 \mu \mathrm{M}$ NAA (Pal et al., $2013 \mathrm{a}$ ). In another study, $\mathrm{Pal}$ argued that he and his colleagues received regenerants of $A$. spinosus from the culture of "hairy" roots. Regenerants were obtained on $\mathrm{MS}_{30}$ medium without growth regulators (spontaneous regeneration) and on $\mathrm{MS}_{30}$ medium $+2 \mathrm{mg} / 1 \mathrm{ZEA}$ (Pal et al., $2013 \mathrm{a}$ ).

Swain and his colleagues obtained A. tricolor regenerants from the culture of "hairy" roots. Regenerants were obtained (on $\mathrm{MS}_{30}$ medium without growth regulators (spontaneous regeneration) and on $\mathrm{MS}_{30}$ medium $+2 \mathrm{mg} / \mathrm{l} \mathrm{ZEA} \mathrm{(Swain} \mathrm{et} \mathrm{al.,} \mathrm{2009;} \mathrm{Swain} \mathrm{et} \mathrm{al.} \mathrm{2010).}$

For clarity, the achievements in the field of callus formation and regeneration is presented in tabular form (Table 1). 
Table 1. Achievements in amaranth regeneration.

\begin{tabular}{|c|c|c|c|}
\hline $\begin{array}{l}\text { Species of amaranth, cultivar, hybrid, } \\
\text { line }\end{array}$ & $\begin{array}{l}\text { Most effective medium for } \\
\text { regeneration }\end{array}$ & Type of explants, age & $\begin{array}{c}\text { Authors, year of publication } \\
\text { Title }\end{array}$ \\
\hline $\begin{array}{l}\text { A. cruentus L. 'Ficha', A. hybridus 'K- } \\
\text { 433'. }\end{array}$ & $\mathrm{MS}_{30}+5 \mathrm{mg} / 1 \mathrm{BA}+0.01 \mathrm{mg} / 1 \mathrm{NAA}$ & epicotyls with 1st pair of leaves & (Gajdošová et al., 2013) \\
\hline $\begin{array}{l}\text { A. cruentus L. 'Ficha', A. hybridus 'K- } \\
\text { 433'. }\end{array}$ & $\begin{array}{l}\mathrm{MS}_{30}+1 \mathrm{mg} / 1 \mathrm{TDZ}, \mathrm{MS}_{30}+3 \mathrm{mg} / 1 \\
\mathrm{TDZ}+0.01 \mathrm{mg} / 1 \mathrm{NAA}\end{array}$ & epicotyls of 10-day seedlings & (Gajdošová et al., 2007) \\
\hline $\begin{array}{l}\text { A. hypohondriacus L., A. cruentus L., } \\
\text { A. tricolor L. }\end{array}$ & $\mathrm{B}_{5}+0.1 \mathrm{mg} / 1+0.1-1.0 \mathrm{mg} / 1 \mathrm{ZEA}$ & hypocotyls & (Flores et al., 1982) \\
\hline A. hypohondriacus L., A. cruentus L. & $\begin{array}{l}\mathrm{MS}_{30}+2 \mathrm{mg} / 1 \mathrm{NAA}+0.2 \mathrm{mg} / 1 \mathrm{BA}+ \\
10 \% \text { coconut water }\end{array}$ & $\begin{array}{l}\text { hypocotyls (non-direct regeneration), leaf } \\
\text { discs }\end{array}$ & (Flores \& Teutonico, 1986) \\
\hline $\begin{array}{l}\text { A. caudatus L., (PI490458, } \\
\text { AMES15114, AMES5461), } \\
\text { A. cruentus L., 434, 622, AMES2248, } \\
\text { AMES2247, PI511731, PI477913) } \\
\text { A. hybridus L. 1047, } \\
\text { A. hypochondriacus L.), 1221, 718, } \\
\text { 674, 722, 412, PI540446) }\end{array}$ & $\begin{array}{l}\mathrm{MS}_{30}+2.7 \mu \mathrm{M} \text { NAA }+2.5 \mu \mathrm{M} 2 \mathrm{iP} \\
2.7 \mu \mathrm{M} \text { NAA }+2.3 \mu \mathrm{M} \text { KIN }) .2 .7 \mu \mathrm{M} \\
\mathrm{NAA}+4.4 \mu \mathrm{M} \mathrm{BA}\end{array}$ & stems & (Bennici et al., 1997) \\
\hline A. caudatus L., A. hypochondriacus L. & $\begin{array}{l}\mathrm{MS}_{30}+0.3 \mathrm{mg} / 1 \mathrm{IAA}+3 \mathrm{mg} / 1 \mathrm{KIN} \\
\mathrm{MS} 30+1 \mathrm{mg} / 1 \mathrm{IAA}+3 \mathrm{mg} / 1 \mathrm{BA} \\
\mathrm{MS}_{30}+6 \mathrm{mg} / 12,4-\mathrm{D}+0.1 \mathrm{mg} / 1 \mathrm{KIN} \\
\mathrm{MS}_{30}+6 \mathrm{mg} / 1 \mathrm{NAA}+0.1 \mathrm{mg} / 1 \mathrm{BA}\end{array}$ & hypocotyls (non-direct regeneration) & (Bennici et al., 1992) \\
\hline A. paniculatus L. & $\begin{array}{l}\mathrm{MS}_{30}+8-15 \mathrm{mg} / 1 \mathrm{KIN} \text { or } 5-10 \mathrm{mg} / 1 \\
\mathrm{BA} ; \\
\mathrm{MS}_{30}+0.5-10 \mathrm{mg} / 1 \quad 2.4-\mathrm{D}+0.5- \\
10 \mathrm{mg} / 1 \mathrm{NAA}\end{array}$ & inflorescence & (Arya et al., 1993) \\
\hline
\end{tabular}


Table 1. Continued.

\begin{tabular}{|c|c|c|c|}
\hline A. edulis $L$. & $\begin{array}{l}\mathrm{MS} 30+2 \mu \mathrm{MTDZ} \\
\mathrm{MS} 30+10 \mu \mathrm{M} \mathrm{CPPU}\end{array}$ & $\begin{array}{l}\text { thin cell layers, obtained from the apical and } \\
\text { sub-apical meristems of 7-day seedlings }\end{array}$ & (Bui van Le et al., 1998) \\
\hline A. paniculatus $\mathrm{L}$. & $\begin{array}{l}\text { B5 KIN (0.5 ppm) and NAA 0.1 } \\
\text { ppm), B5 + } 1 \mathrm{mg} / \mathrm{l} \mathrm{GA3}+1 \mathrm{mg} / 1 \\
\text { KIN + } 1 \mathrm{mg} / 1 \text { 2,4-D. }\end{array}$ & hypocotyls & (Bagga et al., 1987) \\
\hline A. hypochondriacus, cv 'Azteca' L. & $\begin{array}{l}\mathrm{MS}_{30}+13.2 \mu \mathrm{M} \mathrm{BA}+1.08 \mu \mathrm{M} \\
\mathrm{NAA}\end{array}$ & epicotyls and hypocotyls 7 day seedlings & (Jofre-Garfias et al., 1997) \\
\hline A. spinosus L. & $\mathrm{MS}_{30}, \mathrm{MS}_{30}+2 \mathrm{mg} / 1 \mathrm{ZEA}$ & "hairy" roots & (Pal et al., 2013 b) \\
\hline A. tricolor $\mathrm{L}$. & $\begin{array}{l}\mathrm{MS}_{30}+13.2 \mu \mathrm{MBA}+1.8 \mu \mathrm{M} \\
\mathrm{NAA}\end{array}$ & epicotyls and hypocotyls 7 -day seedlings & (Pal et al., 2013 a) \\
\hline A. tricolor $\mathrm{L}$. & $\mathrm{MS}_{30}, \mathrm{MS} 30+2 \mathrm{mg} / \mathrm{ZEA}$ & "hairy" roots & $\begin{array}{l}\text { (Swain et al., 2009; Swain et } \\
\text { al. 2010) }\end{array}$ \\
\hline A. gangenticus L. & $\mathrm{MS}_{30}+2 \mathrm{mg} / \mathrm{NAA}+1 \mathrm{mg} / 1 \mathrm{BA}$ & Leaves, stems, roots & (Amin et al., 1993) \\
\hline A. cruentus $\mathrm{L}$. & $\begin{array}{l}\mathrm{MS}_{30}+1.5 \mathrm{mg} / \mathrm{l} \mathrm{IAA}+0.5 \mathrm{mg} / \mathrm{l} \\
\mathrm{ZEA} ; \mathrm{MS}_{30}+1 \mathrm{mg} / 1 \mathrm{IAA}\end{array}$ & Leaves, stems, roots & (Yaacob et al., 2012) \\
\hline
\end{tabular}




\section{ACHIEVEMENTS IN THE TRANSFORMATION OF AMARANTHUS SPECIES AND FUTURE PROSPECTS}

The next step after obtaining regenerated plants is genetic transformation. The number of studies devoted to genetic transformation of Amaranthus is rather small.

So far, it is reported that genetically transformed parts or whole plants of amaranth have been obtained by two different methods: Agrobacterium-mediated transformation and transformation using the "floral-dip" method.

The Agrobacterium - mediated transformation method was developed on the basis of a natural process. Wild soil bacterium Agrobacterium rhizogenes or tumefaciens is able to infect plants, causing the appearance of "hairy" roots $(A$. rhizogenes) or tumors - crown galls $(A$. tumefaciens). At the same time as the infection process, the transfer and integration of two groups of genes into the plant genome occurs. Genetically modified Agrobacterium transfers the genes of interest or selective genes needed by humans into the plant's genome.

The first experiments on the transformation of amaranths were unsuccessful (De Cleene \& De Ley, 1976). At present, it has been proved that transgenic amaranth plants can be obtained through Agrobacterium-mediated transformation. But still there are very few studies devoted to amaranth transformation.

Transgenic roots were obtained for Amaranthus tricolor L. (Swain et al., 2010) and A. spinosus L. (Pal \& Swain, 2013). Transgenic plants were obtained for A. hypochondriacus L. and A. tricolor L. (Pal \& Swain, 2013; Swain et al., 2009; Swain et al., 2010), A. retroflexus L. (Taipova \& Kuluev, 2015), A. viridis L. (Taipova \& Kuluev, 2015), A. cruentus L. (Taipova \& Kuluev, 2015).

There is no information on the transformation of $A$. caudatus, varieties of which are also used in agriculture.

Transgenic roots were obtained for A. tricolor L. plants by Swain and colleagues (Swain et al., 2010) and for A. spinosus L. by Pal and colleagues (Pal \& Swain, 2013). The transformation of amaranths was carried out using a wild strain of Agrobacterium rhizogenesis A4. Research group Taipova, Kulaev and others obtained transgenic roots for A. cruenthus L. from epicotil segments (Taipova et al., 2019 a; Taipova et al., 2019 b).

Positive results were also obtained in the transformation of amaranth species using strains of Agrobacterium tumefaciens. Jofre-Garfias and co-authors transformed the Azteca variety of A. hypochondriacus L. They used the vector from Agrobacterium tumefaciens with marker genes (Jofre - Garfias et al., 1997). Transgenic A. tricholor L. was obtained by two different groups of scientists - Swain and colleagues and Pal with co-authors (Swain et al., 2009; Pal et al., 2013). A team of researchers headed by Pal used a vector with marker genes.

Taipova and Kulaev obtained regenerated transformed plants from epicotil explants after Agrobacterium-mediated transformation (Taipova et al., 2019 b; Taipova \& Kuluev, 2018).

Castellanos-Arévalo with colleagues obtained transgenic A. hypochondriacus L. and A. hybridus L. from "hairy" roots culture after transformation by $A$. rhizogenes strains ATCC 15834, A4 and HRI. They obtained transgenic plants with rolB, bar, gfp, uidA genes (Castellanos-Arévalo et al., 2020).

There are also 3 studies devoted to amaranth transformation through inflorescences by the "floral-dip" method - Umaiyal Munusamy and co-authors. They used a vector with selective genes (Munusamy et al., 2013).

Another group of researchers - Taipova and Kuluyev - carried out experiments on the transformation of $A$. retroflexus L. (Kuluev et al., 2017; Taipova \& Kuluev, 2015; Taipova et al., 2019 a; Taipova et al., 2019 b), A. viridis (Kuluev et al., 2017; Taipova \& Kuluev, 2015; 
Taipova et al., 2019 a; Taipova et al., 2019 b), A. cruentus L. (Kuluev et al., 2017; Taipova \& Kuluev, 2015; Taipova et al., 2019 a; Taipova et al., 2019 b). They used inflorescences of immature plants for transformation by the "floral-dip" method.

Yaroshko, Kuchuk and co-authors obtained transgenic plants of A. caudatus L. local cultivars Karmin and Helios with bar gene, after transformation by the "floral-dip" method (Yaroshko et al., 2018; Yaroshko \& Kuchuk, 2018) (Figure 1).

Figure 1. Amaranthus caudatus L. cultivars Helios (A) and Karmin (B).
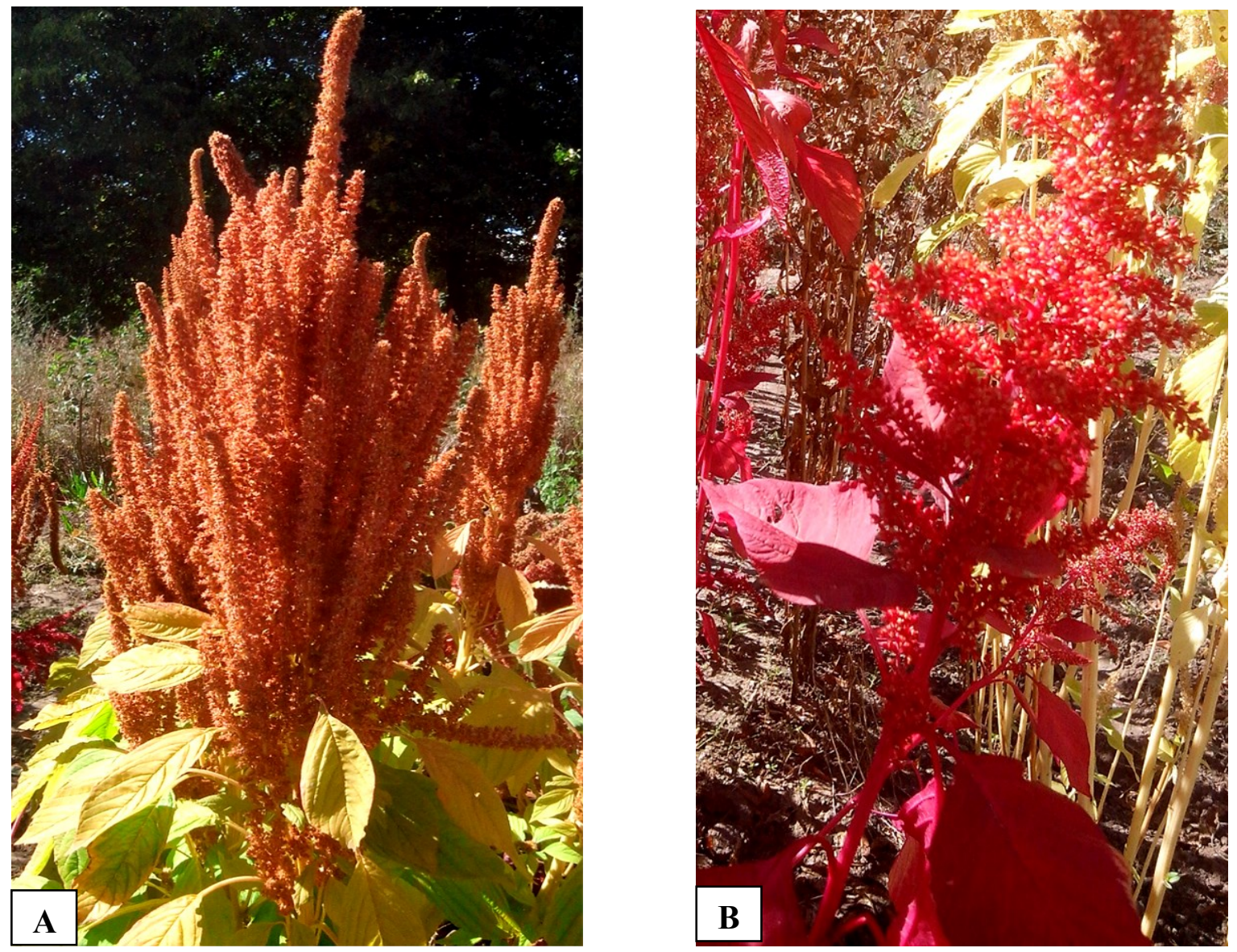

"Floral-dip" method protocols are described in detail in the articles of several authors (Curtis, 2005; Martins et al., 2015). This method was first successfully applied to Arabidopsis thaliana transformation (Clough \& Bent, 1998; Bent, 2006; Harrison et al., 2006; Zhang et al., 2006). In addition, successfully transformed by this method were Brassica rapa via (Hu et al., 2019), Setaria (Saha \& Blumwald, 2016; Sood \& Prasad, 2017; Van Eck, 2018; Van Eck \& Swartwood, 2015), rice (Ratanasut et al., 2017), Schrenkiella parvula (Wang et al., 2019), sugarcane (Mayavan et al., 2015), tomato (Sharada et al., 2017), Eustoma grandiflorum (Fang et al., 2018). The researchers from the Umaiyal Munusamy group, as well as Taipova and Kuluyev, assured that they had obtained viable transgenic seeds.

Yaroshko and Kuchuk obtained transgenic plants of $A$. caudatus L. and hybrids $A$. caudatus L.x A. paniculatus L. after floral-dip transformation (Yaroshko \& Kuchuk, 2018). The researchers Murugan and Sathishkumar obtained only transgenic callus for A. trisis (Murugan \& Sathishkumar, 2016), after transformation of parts of leaves with the Agrobacterium tumefacies strain EHA 105 harboring pCAMBIA 1301 (Murugan \& Sathishkumar, 2016). The achievements in the field of amaranth transformation are presented in tabular form below (Table 2). 
Table 2. Achievements in amaranth transformation.

\begin{tabular}{|c|c|c|c|c|}
\hline $\begin{array}{l}\text { Species of amaranth, } \\
\text { cultivar }\end{array}$ & $\begin{array}{l}\text { Parts of plants used for } \\
\text { transformation }\end{array}$ & $\begin{array}{l}\text { Strain of Agrobacterium used for } \\
\text { transformation }\end{array}$ & Result & Authors, year of publication \\
\hline $\begin{array}{l}\text { A. hypochondriacus } \\
\text { L. "Azteca" }\end{array}$ & germs and cotyledons & $\begin{array}{l}\text { A.tumefaciens pgv } 2260 \text { (pEsc } 4 \text { with genes of } \\
\text { npt II (neomycin phosphotransferase gene) - } \\
\text { kanamycin resistance and uidA (gene of } \beta \text { - } \\
\text { glucuronidase) }\end{array}$ & transgenic plants & (Jofre - Garfias et al., 1997) \\
\hline A. tricolor $\mathrm{L}$. & internodes and leaf blades & A. rhizogenes A4 & transgenic plants & (Swain et al., 2009) \\
\hline A. tricolor $\mathrm{L}$. & internodes and leaf blades & A. rhizogenes A4, LBA9402 & $\begin{array}{l}\text { "hairy" roots, } \\
\text { transgenic plants*** }\end{array}$ & (Swain et al., 2010) \\
\hline A. spinosus $\mathrm{L}$. & internodes and leaf blades & A. rhizogenes LBA9402 & $\begin{array}{l}\text { "hairy" roots, } \\
\text { transgenic plants*** }\end{array}$ & (Pal \& Swain, 2013) \\
\hline A. tricolor $\mathrm{L}$. & epicotyls & $\begin{array}{l}\text { A. tumefaciens EHA } 105, \text { LBA } 4404 \\
\text { (p35SGUSINT with genes of npt II - } \\
\text { kanamycin resistance and uidA for each strain) }\end{array}$ & transgenic plants & (Pal et al., 2013) \\
\hline Amaranthus L.* & inflorescence of adult plants & $\begin{array}{l}\text { A. tumefaciens } A G L 1 \text { ( } p 5 b 5, p 5 d 9, p 5 f 7 \text { with } \\
\text { gene of } h p h \\
\text { (gene codes hygromycin-B- } \\
\text { phosphotransferase protein) }\end{array}$ & transgenic plants & (Munusamy et al., 2013) \\
\hline $\begin{array}{l}\text { A. trisis Willd. (trisis } \\
\text { is the synonym of } \\
\text { Amaranthus dubius } \\
\text { Mart. ex Thell. }\end{array}$ & segments of leaf explants & $\begin{array}{l}\text { A. tumefacies strain EHA } 105 \text { harbouring } \\
\text { pCAMBIA } 1301\end{array}$ & transgenic callus & $\begin{array}{l}\text { (Murugan \& Sathishkumar, } \\
\text { 2016) }\end{array}$ \\
\hline
\end{tabular}


Table 2. Continued.

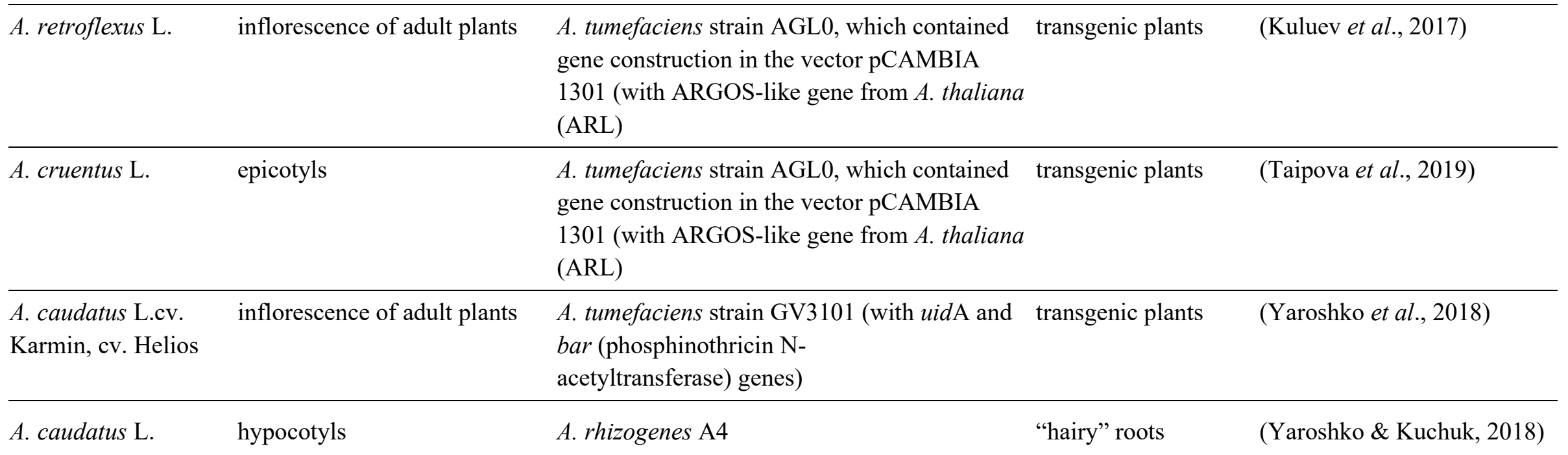

Note: * - name of amaranth species not stated;

** - name of Agrobacterium strain not stated;

*** -authors did not provide enough results in the publication that would confirm exactly the fact of obtaining transgenic plants. 
Thus, at the moment, transgenic amaranth plants have been already obtained with selective genes, marker genes and genes of interest. Research into the transformation of amaranth continues. In the near future, transgenic amaranths may appear that have an improved biochemical composition and new useful properties.

\section{CONCLUSION}

Amaranth is unique plant. Its nutritional value and optimal amino acid composition have already been evaluated in many countries around the world. In Western Europe, the plant has already gained popularity and it is possible find products with amaranth on the shelves of supermarkets. In Ukraine, we also have a small range of products that include amaranth.

At the moment, plant regenerants have been obtained for 9 species of amaranth (A.cruentus L., A. hybridus L., A.hypohondriacus L., A. caudatus L., A. paniculatus L., A. edulis L., A. spinosus L., A. tricolor L., A. gargenticus L.), transformed plants for 6 species (A.hypohondriacus L., A. tricolor L., A. spinosus L., A. retroflexus L., A. viridis L., A. cruentus L.), transformed organs and tissues for 4 species (A. spinosus L., A. trisis L., A. caudatus L., A. tricolor L.).

As can be understood from our previous experimental work and the work of other authors, there are difficulties in achieving regeneration for many species of amaranths. If regenerants are obtained, the percentage of regeneration does not exceed 30 percent, which is clearly not enough for further obtaining transformed plants after agrobacterial transformation.

Therefore, other transformation techniques are being developed, for which it is not necessary to obtain regenerated plants. The alternative transformation method is called 'floral-dip'. According to published studies, transformed plants have been obtained using this method.

At present, mainly transgenic amaranth plants have been obtained, which were transformed by agrobacteria that carried vectors containing selective genes. Only one group of authors obtained transgenic plants with not only selective genes, but also genes of interest.

In the near future, a greater number of amaranth species will be obtained, which will present additional useful features, such as, for example, protein synthesis, which can be used in medicine. The authors hope, that in the near future, amaranth will achieve the position of a recognized niche of the food and medicine industries.

\section{Declaration of Conflicting Interests and Ethics}

The author declares no conflict of interest. This research study complies with research and publishing ethics. The scientific and legal responsibility for manuscripts published in IJSM belongs to the author.

\section{Orcid}

Olha YAROSHKO (D) https://orcid.org/0000-0003-2517-4472

\section{REFERENCES}

Amin, M.A.M., Hasbullah, N. A., Azis, N. A., Daud, N.F., Rasad, F.M., Lassim, M.M. (2015). Morphogenesis studies on Amaranthus gangeticus in vitro: International Conference on Agricultural, Ecological and Medical Sciences (AEMS-2015). 22-24. http://dx.doi.org/10. 15242/IICBE.C0415024

Arya, I. D., Chakravarty, T. N., Sopory, S. K. (1993). Development of secondary inflorescenses and in vitro plantlets from inflorescence cultures of Amaranthus paniculatus. Plant Cell Reports, 12, 286-288. https://doi.org/10.1007/BF00237137 
Bagga, S., Venkateswarlu, K., Sopory, S.K. (1987). In vitro regeneration of plants from hypocotyl segments of Amaranthus paniculatus. Plant Cell Rep., 6, 183-184. https://doi.org/10.1007/BF00268473

Bennici, A., Grifoni, T., Schiff, S., Bovelli, R. (1997). Studies on callus growth and morphogenesis in several species and lines of Amaranthus. Plant Cell Tiss. Organ Cult., 49, 29-33. https://doi.org/10.1023/A:1005882322044

Bennici, A., Schiff, S. (1992). In vitro culture of species and varietes of four Amaranthus L. species. Euphytica., 62, 181-186. https://doi.org/10.1007/BF00041752

Bent, A. Arabidopsis thaliana floral dip transformation method. (2006). Agrobacterium protocols. Methods in Molecular Biology, 343, 87-104. https://doi.org/10.1385/1-59745130-4:87

Biswas, M., Das, S.S., Dey, S. (2013). Establishment of a stable Amaranthus tricolor callus line for production of food colorant. Food Sci. Biotechnol., 22, 22-30. https://doi.org/10.1007/s 10068-013-0041-9

Bui van Le, B., Do My, N. T., Jeanneau, M., Sadik, S., Shanjun, T. J., Vidal, K., Than Van, T. (1998). Rapid plant regeneration of a C4 dicot species: Amaranthus edulis. Plant Science, 132, 45-54. https://doi.org/10.1016/S0168-9452(97)00262-8

Burd, N. B. (2006). Pharmacognostic study of some species of Amaranth genus plants. Manuscript / Thesis for the candidate of pharmaceutical science degree in speciality 15.00.02 - pharmaceutical chemistry and pharmacognosy. National University of Pharmacy, Kharkov.

Castellanos-Arévalo, A., Estrada-Luna, A., Cabrera-Ponce, J., Valencia-Lozano, E., HerreraUbaldo, H., de Folter, S. et al. (2020). Agrobacterium rhizogenes-mediated transformation of grain (Amaranthus hypochondriacus) and leafy (A. hybridus) amaranths. Plant Cell Reports, 39(9), 1143-1160. https://doi.org/10.1007/s00299-020-02553-9

Clough, S. J., Bent, A. F. (1998). Floral dip: A simplified method for Agrobacterium mediated transformation of Arabidopsis thaliana. Plant Journal., 16(6), 735-743. https://doi.org/10.1 046/j.1365-313x.1998.00343.x

Curtis, I.S. (2005). Production of transgenic crops by floral-dip method. Methods in Molecular Biology, 286, 103-109.

De Cleene, M., De Ley, J. (1976). The host range of crown gall. Bot. Rev., 42, 389-466. https://doi.org/10.1007/BF02860827

Fang, F., Oliva, M., Ehi-Eromosele, S., Zaccai, M., Arazi, T., Oren-Shamir, M. (2018). Successful floral-dipping transformation of post-anthesis lisianthus (Eustoma grandiflorum) flowers. The Plant Journal, 96(4), 869-879. https://doi.org/10.1111/tpj.1407 $\underline{6}$

Flores, H. E., Teutonico, R. A. (1986). Amaranths (Amaranthus spp.): Potential grain and vegetable crops. In: Bajaj Y. P. S. (Ed.). Biotechnology in agriculture and forestry, SpringerVerlag, Berlin, Heidelberg, 2, Crops I, 568-577. https://link.springer.com/chapter/10.1007/ 978-3-642-61625-9 32

Flores, H. E., Their A., Galston A. W. (1982). In vitro culture of grain and vegetable Amaranths (spp.). Amer. J. Bot., 69 (7), 1049-1054. https://doi.org/10.2307/2443080

Gajdosova, A. A., Libiakova, G., Fejer, J. (2007). Improvement of selected Amaranthus cultivars by means of mutation induction and biotechnological approaches. Breeding of Neglected and Under-Utilized Crops, Spices and Herbs. Science Publishers., 151-169. researchgate.net/publication/325550233_Improvement_of_Selected_Amaranthus_Cultivar s by Means_of_Mutation_Induction_and_Biotechnological_Approaches (accessed on 08.08.2020).

Gajdosova, A., Libiaková, G., Iliev, I., Hricová, A. (2013). Adventitious shoots induction of Amaranthus cruentus L. Propagation of Ornamental Plants., 13(1), 33-39. 
Harrison S. J., Mott E. K., Parsley K., Aspinall S., Gray J. C. Cottage. (2006). A rapid and robust method of identifying transformed Arabidopsis thaliana seedlings following floral dip transformation. Plant Methods., 2(19). https://doi.org/10.1186/1746-4811-2-19

$\mathrm{Hu}, \mathrm{D} .$, Bent, A., Hou, X., Li, Y. (2019). Agrobacterium-mediated vacuum infiltration and floral dip transformation of rapid-cycling Brassica rapa. BMC Plant Biology, 19(1). https://doi.org/10.1186/s12870-019-1843-6

Jofre-Garfias, A. E., Villegas-Sepúlveda, Cabrera-Ponce, J. L., Adam e-Alvarez, R. M., Herrera-Estrella, L., Simpson, J. (1997). Agrobacterium - mediated transformation of Amaranthus hypochondriacus: light- and tissue-specific expression of a pea chlorophyll a/bbinding protein promoter. Plant Cell Reports, 16, 847-852. https://doi.org/10.1007/s00299 0050332

Kuluev, B. R., Mikhaylova, E. V., Taipova, R. M., Chemeris, A. V. (2017). Changes in phenotype of transgenic amaranth Amaranthus retroflexus L., overexpressing ARGOSLIKE gene. Russian Journal of Genetics, 53(1), 67-75. https://doi.org/10.1134/S10227954 16120061

Martins, P. K., Nakayama, T. J., Ribeiro, A. P., Badbd, C., Nepomuceno, A. L., Harmon, F. G. (2015). Setaria viridis floral-dip: A simple and rapid Agrobacterium-mediated transformation method. Biotechnol. Rep. (Amst.)., 6, 61-63. https://doi.org/10.1016/j.btre.2 $\underline{015.02 .006}$

Mayavan, S., Subramanyam, K., Jaganath, B., Sathish, D., Manickavasagam, M., Ganapathi, A. (2015). Agrobacterium-mediated in planta genetic transformation of sugarcane setts. Plant Cell Reports, 34(10), 1835-1848. https://doi.org/10.1007/s00299-015-1831-8

Munusamy, U., Abdullah, S. N. A., Aziz, M. A., Khazaai, H. (2013). Female reproductive system of Amaranthus as the target for Agrobacterium-mediated transformation, Advances in Bioscience and Biotechnology, 4(2), 188-192. http://dx.doi.org/10.4236/abb.2013.42027

Murugan, S. B., Sathishkumar, R. (2016). Establishment of high frequency callus induction and genetic transformation in neglected leafy vegetable Amaranthus trisis. Austin J. Biotechnol Bioeng. 3(1). 1058.

Pal, A., Swain, S. S., Das, A. B., Mukherjee, A. K., Chand, P. K. (2013 a). Stable germ line transformation a leafy vegetable crop amaranth (Amaranthus tricolor L.) mediated by Agrobacterium tumefaciens, In Vitro Cell. Dev. Biol. Plant., 49, 114-128. https://doi.org/10 .1007/s11627-013-9489-9

Pal, A., Swain, S. S., Mukherjee, A. K., Chand, P. K. (2013 b). Agrobacterium pRi TL-DNA rolB and TR-DNA opine genes transferred to the spiny amaranth (Amaranthus spinosus L.) - A Nutraceutical Crop. Food Technology and Biotechnology., 51(1), 26-35. https://hrcak.s rce.hr/99744

Ratanasut, K., Rod-In, W., Sujipuli, K. (2017). In planta Agrobacterium - mediated transformation of rice. Rice Science, 24 (3), 181-186. https://doi.org/10.1016/j.rsci.2016.11 .001

Saha, P., Blumwald, E. (2016). Spike-dip transformation of Setaria viridis. The Plant Journal, 86 (1), 89-101. https://doi.org/10.1111/tpj.13148

Sharada, M., Kumari, A., Pandey, A., Sharma, S., Sharma, P., Sreelakshmi, Y., Sharma, R. (2017). Generation of genetically stable transformants by Agrobacterium using tomato floral buds. Plant Cell, Tissue and Organ Culture (PCTOC), 129(2), 299-312. https://doi.org/10. 1007/s11240-017-1178-7

Sood, P., Prasad, M. (2017). Genetic transformation of Setaria: A new perspective. Compendium of Plant Genomes., 105-121. https://doi.org/10.1007/978-3-31965617-5 9

Swain, S.S., Sahu, L., Barik, D.P., Chand, P.K. (2009). Genetic transformation of Amaranthus tricolor L. using Ri plasmid vectors. In: Bastia, AK. and Mohapatra UB. (eds.) Recent trends 
in monitoring and bioremediation of mine and industrial environment. Proc. Natl. Sem., North Orissa University, Orissa, 109-116.

Swain, S. S., Sahu, L., Barik, D. P., Chand, P. K. (2010). Agrobacterium plant factors influencing transformation of "Joseph's coat" (Amaranthus tricolor L.). Scientia Horticulturae, 125, 461-468. https://doi.org/10.1016/j.scienta.2010.04.034

Taipova, R. M., Kuluev, B. R. (2015). Amaranth features of culture, prospects of cultivation in Russia and generation of transgenic Russian varieties/Амарант: особенности культуры, применение, перспективы возделывания в России и создание трансгенных отечественных сортов [in Russian]. Biomika, 7(4), 284-299.

Taipova, R., Musin, K., Kuluev, B. (2019 a). Obtaining hairy roots of Amaranthus cruenthus L. and evaluation of their growth indicators. Ekobioteh., 2(4), 574-581. https://doi.org/10.31163/2618-964X-2019-2-4-574-581

Taipova, R., Musin, K., K., Kuluev, B. (2019 b). Agrobacterium-mediated transformation of Amaranthus cruentus L. Epicotils. Journal of Siberian Federal University. Biology, 13(2), 1-9. https://doi.org/10.17516/1997-1389-0292

Taipova, R., Kuluev, B. (2018). Introduction to in vitro culture and regeneration of shoots from epicotyl explants of Amaranthus cruentus/ Введение в культуру и регенерация побегов из эксплантов эпикотилей амаранта Amaranthus cruentus. Vesnik Biotehnologii, 14(1), 64-66.

Tisserat, B., Galletta, P. D. (1988). In vitro flowering in Amaranthus. HortScience, 23, 210 212.

Van Eck, J. (2018). The status of Setaria viridis transformation: Agrobacteriummediated to floral dip. Frontiers in Plant Science, 9. https://doi.org/10.3389/fpls.2018.0065 $\underline{2}$

Van Eck, J., Swartwood, K. (2015). Setaria viridis. Methods in Molecular Biology, 1223, 5767. https://doi.org/10.1007/978-1-4939-1695-5_5

Wang, G., Pantha, P., Tran, K., Oh, D., Dassanayake, M. (2019). Plant growth and Agrobacterium-mediated floral-dip transformation of the extremophyte Schrenkiella Parvula. J. Vis. Exp., 143. https://doi.org/10.3791/58544

Yaacob J. S, Hwei L. C., Taha R. M. (2012). Pigment analysis and tissue culture of Amaranthus cruentus L.. Acta Horticulturae, 54-64. https://doi.org/10.17660/ActaHortic.2 $\underline{012.958 .20}$

Yaroshko, O., Vasylenko, M., Gajdošová, A., Morgun, B., Khrystan, O., Velykozhon, L., Kuchuk, M. (2018). "Floral-dip" transformation of Amaranthus caudatus L. and hybrids A. caudatus A. paniculatus L. Biologija, 64(4), 321-330. https://doi.org/10.6001/bi ologija.v64i4.3904

Yaroshko, O. M., Kuchuk, M. V. (2018). Agrobacterium - caused transformation of cultivars Amaranthus caudatus L. and hybrids of A. caudatus L. x A. paniculatus L. International Journal of Secondary Metabolite, 5(4), 312-318. https://doi.org/10.21448/ijsm.478267

Zhang, X., Henriques, R., Lin, S. S., Niu, Q., Chua, N. H. (2006). Agrobacterium mediated transformation Arabidopsis thaliana of Arabidopsis thaliana using the floral dip method. Nature Protocols, 1, 1-6. https://doi.org/10.1038/nprot.2006.97 